\title{
Effect of surface sealant on the surface roughness of different composites and evaluation of their microhardness*
}

\section{Purpose}

The aim of this study was to evaluate the effect of a surface sealant on the surface roughness of different composites and compare their microhardness values.

\section{Materials and Methods}

Sixty disc-shaped specimens were prepared and assigned to 6 groups ( $n=10$ ). Groups were prepared as follows; Group 1 (Herculite XRV Ultra), Group 2 (Beautifil Bulk Restorative) and Group 3 (Filtek Bulk Fill Posterior Restorative). Groups 4, 5, and 6 were prepared by applying a surface sealant (BisCover LV) on the specimens in groups 1, 2 and 3. Surface hardness of the discs in group 1,2, and 3 and surface roughness of the discs in all groups were measured using the Vickers hardness test and a profilometer, respectively. One-way ANOVA was used to test for differences among the groups.

\section{Results}

No significant differences were observed in the microhardness and roughness between the experimental and control groups for each restorative materials. Group 3 showed the highest surface hardness and group 4 showed the lowest surface roughness values.

\section{Conclusion}

Using the BisCover LV resin after the polishing step has no significant effect on the surface roughness. The highest hardness values were obtained for the Filtek Bulk Fill Posterior Restorative after the polishing step. The smoothest surfaces were obtained for all experimental groups using the BisCover LV resin after the polishing step, Herculite XRV Ultra showed lower average roughness values than the other materials.

Keywords: Roughness; microhardness; resin composite; surface sealant; mechanical properties

\section{Introduction}

Dental composite resins are commonly used restorative materials for the replacement of defects in hard dental tissues $(1,2)$. Despite of satisfactory mechanical and esthetic properties, they have some disadvantages too. Polymerization shrinkage causes some problems such as postoperative sensitivity, secondary caries and marginal leakage. To remove these problems, less than 2-mm- thick layering should be done and it is a time-consuming process. Thus, bulk fill composites have been produced that are claimed to have a low shrinkage stress (3).

Regardless of the cavity class, location and type of the composite material, a smooth surface finish is clinically important because it determines the esthetics and longevity of composite resin restorations (4). Proper finishing of restorations is desirable not only for esthetics but also for good oral health by preventing plaque retention (5). Surface roughness of dental materials can cause microtrauma to the oral tissues and enhance the

\author{
Ozge Gurbuz' ${ }^{1}$, \\ Aylin Cilingir ${ }^{2}(\mathbb{D}$, \\ Benin Dikmen $^{1} \mathbb{D}^{\mathrm{D}}$, \\ Alev Ozsoy' ${ }^{1}$, \\ Meltem Mert Eren ${ }^{3}$
}

Presented at: 47th Meeting of the Continental European Division of the International Association for Dental Research (CED-IADR)

ORCID IDs of the authors: Ö.G. 0000-0002-3468-950X A.C.. 0000-0002-9848-9136; B.D. 0000-0003-2174-8934; A.O. 0000-0001-9589-3232; M.M.E. 0000-0002-5903-6636

'Istanbul Medipol University, Faculty of Dentistry, Department of Restorative Dentistry, Istanbul, Turkey

${ }^{2}$ Trakya University, Faculty of Dentistry, Department of Restorative Dentistry, Edirne, Turkey

${ }^{3}$ Altınbas University, Faculty of Dentistry, Department of Restorative Dentistry, Istanbul, Turkey

Corresponding Author: Aylin Cilingir

E-mail: aylincinar@hotmail.com

Received: 11 February, 2019 Revised: 26 April, 2019 Accepted: 27 May, 2019

DOI: $10.26650 /$ eor.20200020 
retention of microorganisms, thereby contributing directly or indirectly to tissue injuries and possible oral diseases $(6,7)$. Therefore, a smooth surface finish is important to maintain good oral health by reducing microorganism retention and plaque accumulation as well as for good esthetic appearance and less recurrent caries and gingival irritation (8-11). Moreover, average surface roughness $(\mathrm{Ra})$ above the $0.2 \mu \mathrm{m}$ threshold has been reported to increase the colonization and adhesion of bacteria on composite resin surfaces (12). The surface roughness of composite resin is usually determined by the size, hardness, and amount of the filler particles, flexibility of the material, and the hardness and grit size of the abrasive (13).

It has been shown that the surface micromorphology of composite resins after finishing and polishing steps can be influenced by the size, hardness and amount of the filler particles (14). During the polishing of hybrid composites, the harder filler particles are left protruding from the surface, whereas the softer resin matrix is preferentially removed. Therefore, the harder filler particles should be packed close together to protect the soft resin matrix from abrasives (15). The combination of reduced particle dimensions and wider size distribution allows the higher levels of filler loading, resulting in reduced polymerization shrinkage and improved mechanical properties (16). To achieve an effective finishing system for composite resins, the abrasive particles should be relatively harder than the filler materials to prevent the preferential removal of the soft resin matrix during polishing, leaving the harder filler particles protruding from the surface (13). According to earlier work, larger filler particles have resulted in greater Ra values $(17,18)$. The composite resins with higher concentrations of small-sized filler particles have become popular in recent years due to the difficulties in producing smooth surfaces similar to the enamel surface using the composite resins that have larger filler particles. Typically, increased amounts of filler particles result in smoother surfaces because of the decreased particle size and better particle distribution within the resin matrix (13).

Surface sealants have been developed to preserve or improve the mechanical properties of direct restorative materials $(19,20)$. Thus, application of the surface sealants after the polishing step has been recommended to increase the longevity of restorations $(21,22)$. Liquid polishing materials are low-viscosity, light-polymerized resin formulations with a low amount of filler particles that provide a smooth, sealed surface for interim and composite resin restorations $(14,23,24)$. Surface penetrating sealants (SPS) are unfilled low-viscosity resins polymerized onto the composite surfaces to promote the filling of structural microdefects and microfissures by capillary action (25) for maintaining the surface smoothness, improving the wear resistance $(25,26)$ and marginal sealing (27) of the restoration. Since various surface defects such as microcracks and irregularities are formed due to the removal of some of the surface particles during finishing, application of the liquid resin to the finished material surface has been

recommended to repair the structural microdefects and improve the abrasion resistance of posterior composite resins $(28,29)$.

However, the effectiveness of sealants in improving the smoothness of composite surfaces is still controversial. Although some authors have suggested that sealants might be desirable to improve the surface finishing of composites $(21,30)$, others have reported no significant reduction in the surface roughness of composites after the simulated abrasion test (31) and also in clinical evaluations after one and five years $(25,32)$.

Substantial surface hardness of the restoration is one of the main requirements in high stress- bearing areas such as posterior restorations (33) Materials which have reduced surface hardness are more susceptible to deformation (34). Microhardness can be influenced by monomer type, filler type, morphology,volume and weight (34-36). Moreover, finishing and polishing of the restoration can affect the hardness of the composite materials (34).

There are some studies that compare microhardness of different bulk fill composite materials and declare various results (37-41). It is stated that bulk fill composites with low filler content showed lower microhardness than with high filler contents $(3,42,43)$. Despite of various results about the microhardness of different bulk fill composites, there has been no previously reported study that compare the microhardness of bulk fill composites chosen in our study each other.

The aim of this study was to evaluate the effect of the BisCover LV resin sealant on the roughness of different composites and compare their microhardness values. Based on this information, the following hypotheses were tested: (1) surface sealant reduces the roughness of composite materials (2) there were no significant difference between the microhardness of the composite materials used in this study.

\section{Materials and Methods}

\section{Specimen preparation}

Ten disc-shaped specimens with $10 \mathrm{~mm}$ in diameter and $2 \mathrm{~mm}$ in thickness were prepared in a teflon mold for each study group (Figure 1)(11). Total sixty disc-shaped specimens were prepared for the surface property tests and divided into 6 groups. Different study groups and materials used

\begin{tabular}{|c|c|c|c|c|c|c|}
\hline$n=10$ & group 1 & group 2 & group 3 & group 4 & group 5 & group 6 \\
\hline $\begin{array}{l}\text { Composite } \\
\text { restoration }\end{array}$ & $\begin{array}{l}\text { Herculite } \\
\text { XRV Ultra }\end{array}$ & $\begin{array}{l}\text { Beautifil } \\
\text { Bulk } \\
\text { Restorative }\end{array}$ & $\begin{array}{l}\text { Filtek } \\
\text { BulkFill }\end{array}$ & $\begin{array}{l}\text { Herculite } \\
\text { XRV Ultra }\end{array}$ & $\begin{array}{l}\text { Beautifil } \\
\text { Bulk } \\
\text { Restorative }\end{array}$ & $\begin{array}{l}\text { Filtek } \\
\text { BulkFill }\end{array}$ \\
\hline $\begin{array}{l}\text { BisCover } \\
\text { application after } \\
\text { restoration }\end{array}$ & - & - & - & + & + & + \\
\hline
\end{tabular}


Table 2. Characteristics of materials tested

\begin{tabular}{|c|c|c|c|c|c|}
\hline & Composition & Manufacturer & Classification & Filler & Filler loading \\
\hline Herculite XRV Ultra & $\begin{array}{l}\text { Ethoxylated } \\
\text { Bis-GMA, } \\
\text { TEGDMA, } \\
\text { BisEMA }\end{array}$ & $\begin{array}{l}\text { Kerr, Orange, } \\
\text { CA, USA }\end{array}$ & $\begin{array}{l}\text { Nano-hybrid } \\
\text { composite }\end{array}$ & $\begin{array}{l}\mathrm{SiO}_{2} \text {, Barium } \\
\text { silicate glass, } \\
\text { Prepolymerized } \\
\text { filler with } \\
\text { barium silicate } \\
\text { glass and silica }\end{array}$ & $\begin{array}{l}71 \mathrm{wt} \% / 54 \\
\text { vol\% }\end{array}$ \\
\hline $\begin{array}{l}\text { Beautifil Bulk } \\
\text { Restorative }\end{array}$ & $\begin{array}{l}\text { Bis-GMA, } \\
\text { UDMA, Bis- } \\
\text { MPEPP, } \\
\text { TEGDMA }\end{array}$ & $\begin{array}{l}\text { Shofu Inc, } \\
\text { Kyoto, Japan }\end{array}$ & $\begin{array}{l}\text { Giomer based } \\
\text { bulk fill resin } \\
\text { composite }\end{array}$ & $\begin{array}{l}\text { Surface } \\
\text { modified } \\
\text { prereacted glass } \\
\text { (S-PRG) filler } \\
\text { based on } \\
\text { fluoroboroalumi } \\
\text { nosilicate glass, } \\
\text { polymerization } \\
\text { initiator }\end{array}$ & $\begin{array}{l}87 \text { wt } \% / 74.5 \\
\text { vol } \%\end{array}$ \\
\hline Filtek BulkFill & $\begin{array}{l}\text { Bis-GMA, UDMA, Bis- } \\
\text { EMA(6), } \\
\text { procrylat resins }\end{array}$ & $\begin{array}{l}\text { 3M ESPE, St. Paul, } \\
\text { MN, USA }\end{array}$ & $\begin{array}{l}\text { Bulk-fill paste } \\
\text { composite with } \\
\text { glass microfibres }\end{array}$ & $\begin{array}{l}\text { Zirconia/Silica, } \\
\text { ytterbium } \\
\text { trifloride }\end{array}$ & $\begin{array}{l}76.5 \text { wt } \% / 58.5 \\
\text { vol\% }\end{array}$ \\
\hline Biscover LV & $\begin{array}{l}\text { Dipentaerythrrit } \\
\text { ol pentaacrylate } \\
\text { esters and Etanol }\end{array}$ & $\begin{array}{l}\text { Bisco Inc, } \\
\text { Schaumburg, } \\
\text { IL, USA }\end{array}$ & $\begin{array}{l}\text { Low-viscosity } \\
\text { liquid polish }\end{array}$ & & \\
\hline
\end{tabular}

in this study are outlined in Table 1, and the properties and type of the used materials are presented in Table 2. The composite resins were poured in a Teflon mold covered with a polyester strip and a glass slide ( $1 \mathrm{~mm}$ thick) was then placed over the polyester strip to flatten the surfaces according to the composite manufacturer's recommendation. The restorative materials were light-cured (Optilux Demetron, VLC 403, Danbury, CT, USA, $500 \mathrm{~mW} / \mathrm{cm}^{2}$ ). Herculite XRV Ultra was applied into the mold and light-cured for $20 \mathrm{~s}$. Beautifil Bulk Restorative and Filtek BulkFill were applied into the mold and light-cured for $20 \mathrm{~s}$ and $40 \mathrm{~s}$, respectively. Afterwards, the surfaces of the specimens were polished for $30 \mathrm{~s}$ from extra- coarse grain size to extra-fine grain size with polishing discs (OptiDisc, Kerr Hawe, Karlsruhe, Germany). A new polishing disc was used for each specimen and then discarded after each use. Specimens in experimental groups 4, 5, and 6 were etched with $32 \%$ phosphoric acid (Uni- Etch, Bisco Inc.,

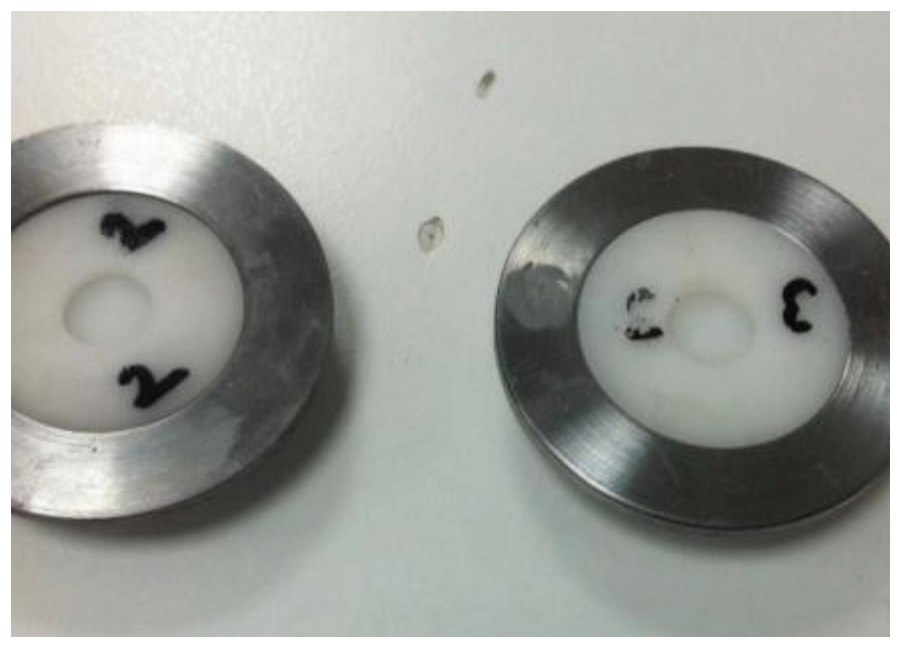

Figure 1. Teflon mold for composites specimens.
Schaumburg, IL, USA) for $15 \mathrm{~s}$. Then, the etched specimens were rinsed with water and air dried before directly applying the BisCover LV resin (dipentaerythritol pentaacrylate in ethanol) (BisCover, Bisco Inc., Schaumburg, IL, USA) using a syringe and an applicator tip. After a $15 \mathrm{~s}$ wait for ethanol vaporization, specimens were light polymerized for $30 \mathrm{~s}$ with Optilux as the manufacturer's instruction. The light curing unit tip was positioned perpendicular to the specimens' surfaces, and the distance between the tip and the specimen was standardised using a glass microscope slide $(1 \mathrm{~mm}$ in thickness). All samples were stored in distilled water at $37^{\circ} \mathrm{C}$ for 24 hours. This research was conducted at Istanbul Medipol University and Istanbul University Laboratory.

\section{Microhardness measurements}

Surface hardness of different composite resins was measured using the Vicker's hardness test because of its easeof-use and reliability of the measurements (44). The microhardness values for the samples in groups 1, 2, and 3 were obtained using an Innovatest Nexus 4503 hardness testing machine (Innovatest Europe, Maastricht, The Netherlands) for loads of 2.5 - $10 \mathrm{kgf}(24.51-98.07 \mathrm{~N})$ (Figure 2). The surface hardness measurements were performed using a microscope at 20x magnification under a load of $300 \mathrm{~g}$ for $15 \mathrm{~s}$. The applied load and the hold time were kept constant for all samples throughout the study. The measurement was carried out three times in each sample at random locations and a mean value was calculated.

\section{Surface roughness measurements}

Surface roughness of different composite resins was determined using the roughness average ( $\mathrm{Ra}$ ) parameter, which represents the arithmetic average of absolute values 


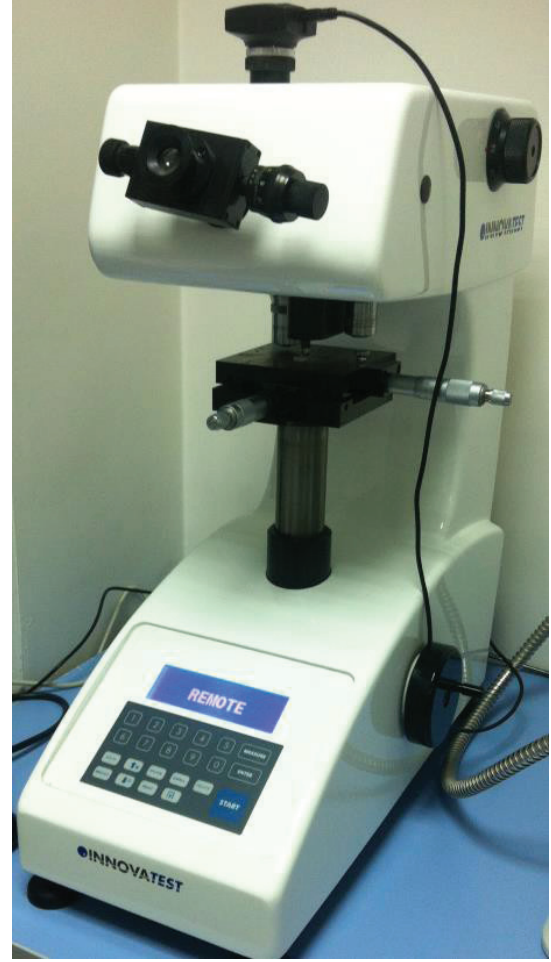

Figure 2. Hardness testing machine.

of the profile height deviations from the mean line recorded within the evaluation length (45). A profilometer (Taylor Hobson Surtronic 25, UK) was used for measuring the Ra values of groups 1, 2, 3, 4, 5, 6 with a cut-off value of $0.8 \mathrm{~mm}$, a transverse length of $0.8 \mathrm{~mm}$, and a stylus speed of $0.1 \mathrm{~mm} /$ seconds. For surface roughness test, readings were taken at three random locations on each surface and the average roughness value $(\mathrm{Ra}, \mu \mathrm{m})$ was obtained by using the arithmetic mean of these three readings.

\section{Statistical analysis}

Statistical analysis of the data was performed with Statistical Package for Social Sciences (SPSS) statistical software (SPSS PC, Vers.15.0; SPSS Inc.; Chicago, IL, USA). Descriptive statistics for continuous variables were calculated and reported in a mean \pm standard deviation format. To detect differences among $\mathrm{Ra}$ and microhardness values for different groups, a one- way analysis of variance (ANOVA) method was used at the 0.05 level of significance.

\section{Results}

Mean microhardness and roughness values for different groups are presented in Table 3 and Table 4. There were no significant differences in microhardness and roughness values between the experimental and control groups for each restorative material ( $p>0.05)$. Based on the test results, group 3 showed the highest surface hardness and group 4 showed the lowest surface roughness values.

\section{Discussion}

The clinical significance of surface roughness and hardness is related to the esthetic restorations (discoloration and wear), the medical consequences of periodontal disease, and the development of secondary caries due to increased plaque accumulation. Wear and microleakege are the main limitations of the composite resins in mainly posterior restorations (46). Several research groups have studied the surface characteristics of different restorative materials (11,31,47-49) using contact profilometers, which detect surface irregularities using a stylus moving vertically across the surface. In addition, clinical studies have shown that the rough surfaces

Table 3. Mean microhardness values and differences within groups

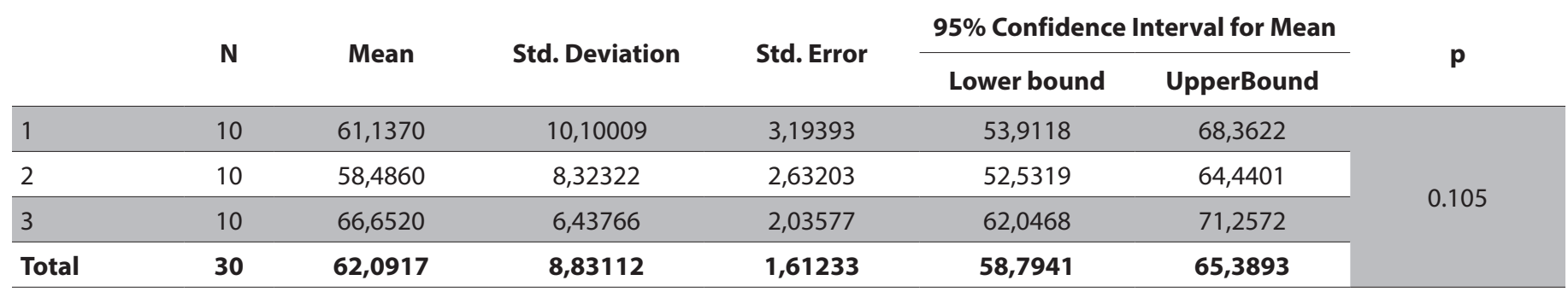

Table 4. Mean Roughness (Ra) values and differences within groups

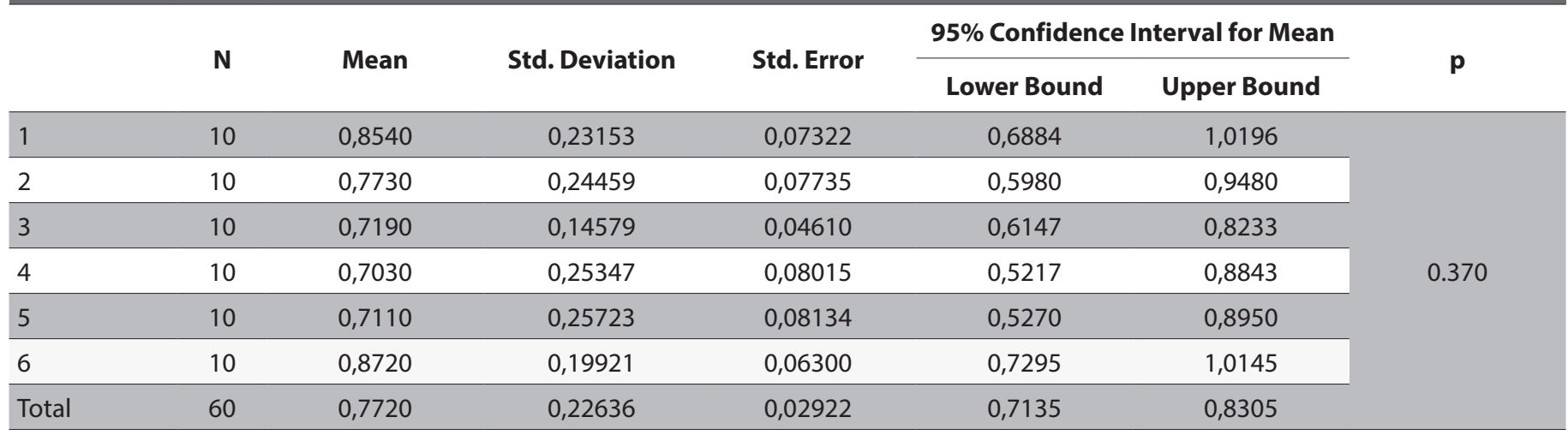


can promote plaque formation and reduce the efficiency of teeth cleaning procedures (50). Bollen et al. reported that a Ra of $0.2 \mu \mathrm{m}$ or more could result in accumulation of bacterial plaque, thereby promoting the periodontal diseases and carious lesions (12). However, results from this study showed that the mean Ra and microhardness values obtained at the baseline for the experimental and control groups did not differ statistically from each other.

Effective surface sealants should have good surface wettability, a low contact angle, a low viscosity, and good penetration capability. Microgaps may occur between tooth/ restoration interface depending on the polymerization shrinkage during restoring the tooth with resin composites. Surface sealants minimize the wear rates of the resins by filling the microdefects on the restorations (46). Therefore, the presence of low molecular weight monomers was found to be essential in dental sealants (47). It was assumed that a surface sealant containing Bis- GMA combined with low molecular weight monomers (TEGDMA and THFMA) would control its desirable characteristics such as viscosity and surface wettability (25). Also fillers were added to some selants to increase their mechanical properties (46).

The wear resistance of composite resins can be enhanced with a surface sealant, as long as it is annually applied. In an in vivo study, the researchers found that the wear values of the sealed restorations after one year were approximately half of those found in the non-sealed restorations

(25). In addition, these low viscosity resins can increase the wear resistance of the tooth/restoration interface in luting indirect restorations (26).

Although relatively smoother surfaces were obtained with the polyester strips, the use of a glazing material after the polishing step resulted in significantly lower Ra values compared to that obtained with the use of polyester strips alone. The glazing material appeared to fill the structural microdefects, thereby providing a more uniform and smooth surface (30). However, some initial investigations demonstrated the degradation of the glazing materials over time, in spite of their resistance to toothbrushing and staining $(31,46,51)$. Therefore, the limitations of this in vitro study have to be developed and improved in terms of aging.

The effectiveness of sealants in improving the smoothness of composite surfaces is still controversial. Although some authors have suggested that sealants might improve the surface finish (30), others have reported no significant reduction in the surface roughness of composites after the simulated toothbrushing abrasion test and also in clinical evaluations after one and five years (25). The complex structure of a surface cannot be fully characterized by the use of only surface roughness measurements (15).

According to Shintani and others, there were no noticeable differences in plaque accumulation among the surfaces polished using different methods, which resulted in $\mathrm{Ra}$ values within the range of 0.7-1 $\mu \mathrm{m}$ (52). Chung reported that restorations with less than $1 \mu \mathrm{m}$ surface roughness appeared to be optically smooth (14).

The inherent surface roughness of composite resins should be equal or lower than the surface roughness of enamel-to-enamel occlusal contact areas ( $R a=0.64 \mu \mathrm{m})$. When comparing the roughness values of optimally polished surfaces, mostly the surface roughness values produced by pressing the restorative materials against transparent matrices such as Mylar strips (53).

Thus, very smooth polished surfaces representative of the clinical situation can be obtained using clear matrices. Although the surface obtained with Mylar strip is perfectly smooth, it is rich in resin organic binder (53). Therefore polishing discs were used to mimic the clinic conditions before applying the surface sealant in this study.

It has been reported that a noticeable decrease in mean surface roughness could be achieved within first five seconds of polishing for practically all restorative materials, but a further decrease of the same magnitude could not be obtained with longer polishing times or the application of additional components (54). Thus, one-step polishing systems offer time saving benefit along with reduced roughness when polishing the composite restorations. Based on this fact one-step surface sealant was used when evaluating the resin surfaces in this study.

The first tested hypothesis was rejected because the surface sealant material decreased the surface roughness of composite resins, but there were no significant differences in the roughness values between the experimental and control groups for each restorative material. Different results may be obtained with different polishing techniques and composite resin materials.

Several factors related to the composite resin compositions were shown to affect the surface hardness of the composite restorative materials (54). It was observed that the mass fraction $(55,56)$, size, and distribution of filler particles have significant effects on certain physical and mechanical properties, including surface hardness of the composite resins $(57,58)$. Moreover, other parameters such as filler particle shape and density, monomer type and ratio, degree of crosslinking, and photoinitiators have also shown significant influence on the surface hardness of restorative materials $(55,59)$.

A microhardness test gives information as to the mechanical properties of the material. A positive correlation has been determined between the hardness and inorganic filler content of composites. Increased organic filler levels result in increased hardness values $(60,61)$.

In a study on filler particle size effect, significant high differences were noticed in the VHN (Vickers hardness number) mean values among bulk-fill and incrementally-fill composite resins, either for top or bottom surfaces. The highest VHN value was obtained for the incremental-fill nanohybrid composite (Grandio) compared to that of the two bulk-fill microhybrid composites (X-tra fil and QuiXfil) (62). According to Moszner et al. (16) and Thome et al. (63), the microhybrid composite resins exhibited higher microhardness values than that of the nanohybrid composite resin.

The second tested hypothesis that, there were no significant differences between the microhardness of the composite materials used was accepted. Despite there were no significant differences between the groups tested, group 3 had the highest microhardness values. This could be attributed to the filler particles of (glass microfibres, zirconia, silica and ytterbium trifloride) the Filtek Bulk-fill. Also it can be speculated that bulk-fill resin composites allow more light to penetrate deep inside and which can results in more polymerized monomers. Our finding's in agreement with a previous study (64). 
Therefore, further investigation is necessary to evaluate the surface roughness and microhardness values for different composite resins and polishing techniques.

\section{Conclusion}

In this study, the highest hardness values were obtained using Filtek Bulk Fill Posterior Restorative (silane treated ceramic, 3M-ESPE, Germany) after the polishing step. The smoothest surfaces were obtained using a surface sealant after the polishing step, Herculite

XRV Ultra showed lower Ra values compared with those of the other restorative materials. No significant differences were found in the surface roughness of selected composite resins sealed with BisCover LV. Similarly, the microhardness values showed no significant differences among different composite resin materials. Hardness value obtained for group 3 is higher but not significantly different compared to that of the groups 1 and 2 . As a result, the glazing material showed a negligible effect on the surface roughness values of different polished composite resins. The current generation of composite resins focused on the filler particle size (nano-fill and bulk- fill) have improved the surface properties such as hardness and roughness of restorative materials. Therefore, the use of sealants to improve the smoothness and hardness of these composite restorations is questionable. Longitudinal clinical trials are necessary to validate this hypothesis and provide further insights into the design of composite resins for clinical use.

Türkçe Öz: Yüzey örtücü materyalin farklı kompozitlerin yüzey pürüzlülüğü ve mikrosertliği üzerine etkisinin değerlendirilmesi. Amaç: Bu çalışmanın amacı, bir yüzey örtücü materyalin, farklı kompozitlerin yüzey pürüzlülüğü üzerindeki etkisini değerlendirmek ve mikro sertlik değerlerini karşılaştırmaktır. Gereç ve yöntem: Altmış adet disk şeklindeki test numunesi hazırlanmış ve 6 gruba ayrılmıştır $(n=10)$. Gruplar aşağıdaki gibi hazırlanmıştır; Grup 1 (Herculite XRV Ultra), Grup 2 (Beautifil Bulk Restorative) ve Grup 3 (Filtek Bulk Fill Posterior Restorative). Grup 4, 5 ve 6 da sırasıly grup 1, 2 ve 3'te kullanılan restoratif materyallere ek olarak bir yüzey örtücü materyal (BisCover LV) kullanılmıştır. Daha sonra Grup 1, 2 ve 3'teki disklerin yüzey sertliği ve tüm gruplardaki disklerin yüzey pürüzlülüğü sırasıyla Vickers sertlik testi ve bir profilometre kullanılarak ölçülmüştür. Gruplar arasındaki farklılıkları test etmek için tek yönlü ANOVA kullanılmıştır. Bulgular: Her bir restoratif materyal için deney ve kontrol grupları arasında mikro sertlik ve pürüzlülük açısından istatiksel olarak anlamlı bir fark gözlenmemiştir. Grup 3 en yüksek yüzey sertliğini, grup 4 ise en düşük yüzey pürüzlülüğünü göstermiştir. Sonuç: Cila aşamasından sonra bir yüzey örtücü (BisCover LV) kullanılması farklı kompozitlerin yüzey pürüzlülüğü üzerinde istatistiksel olarak anlamlı bir etkiye sahip değildir. En yüksek sertlik değerleri, cila aşamasından sonra Filtek Bulk Fill Posterior Restorative için elde edilmiştir. Tüm deney grupları için cila aşamasından sonra yüzey örtücü (BisCover LV) kullanılarak en pürüzsüz yüzeyler elde edilmiştir. Herculite XRV Ultra diğer materyallere göre daha düşük bir ortalama pürüzlülük değeri vermiştir. Anahtar kelimeler: Pürüzlülük; mikro sertlik; rezin kompozit; yüzey örtücü materyal, mekanik özellikler.

Ethics Committee Approval: Not required.

Informed Consent: Not required.

Peer-review: Externally peer-reviewed.

Author contributions: $\mathrm{OG}, \mathrm{AC}$ and $\mathrm{BD}$ designed the study. $\mathrm{OG}, \mathrm{AC}$, $\mathrm{BD}$ and $\mathrm{MME}$ participated in generating the data for the study. $\mathrm{AO}$ and MME participated in gathering the data for the study. OG, AC and $\mathrm{AO}$ participated in the analysis of the data. $\mathrm{OG}$ and $\mathrm{BD}$ wrote the majority of the original draft of the paper. $O G, A C$ and $A O$ participated in writing the paper. All authors approved the final version of this paper.

Conflict of Interest: The authors had no conflict of interest to declare.

Financial Disclosure: The authors declared that this study has received no financial support.

\section{References}

1. Abbasi M, Moradi Z, Mirzaei M, Kharazifard MJ, Rezaei S. Polymerization Shrinkage of Five Bulk-Fill Composite Resins in Comparison with a Conventional Composite Resin. J Dent (Tehran) 2018;15(6):365-74. [CrossRef]

2. Malek Afzali B, Ghasemi A, Mirani A, Abdolazimi Z, Akbarzade Baghban A, Kharazifard MJ. Effect of Ingested Liquids on Color Change of Composite Resins. J Dent (Tehran) 2015;12(8):577-84.

3. Son SA, Park JK, Seo DG, Ko CC, Kwon YH. How light attenuation and filler content affect the microhardness and polymerization shrinkage and translucency of bulk-fill composites? Clin Oral Investig 2017; 21(2): 559-65. [CrossRef]

4. Yap AU, Yap SH, Teo CK, Ng JJ. Finishing/polishing of composite and compomer restoratives: effectiveness of one-step systems. Oper Dent 2004;29:275-9.

5. Yap AU, Tan S, Teh TY. The effect of polishing systems on microleakage of tooth coloured restoratives: part 1. Conventional and resin-modified glass-ionomer cements. J Oral Rehabil 2000;27:117-23. [CrossRef]

6. Abuzar MA, Bellur S, Duong N, Kim BB, LuP,Palfreyman N,etal. Evaluating surface roughness of a polyamide denture base material in comparison with poly (methyl methacrylate). J Oral Sci 2010;52:577-81. [CrossRef]

7. Chatzivasileiou K, Emmanouil I,Kotsiomiti E,Pissiotis A. Polishing of denture base acrylic resin with chairside polishing kits: an SEM and surface roughness study. Int J Prosthodont 2013;26:7981. [CrossRef]

8. Sarikaya I, Güler AU. Effects of different polishing techniques on the surface roughness of dental porcelains. J Appl Oral Sci 2010;18:10-6. [CrossRef]

9. Giacomelli L, Derchi G, Frustaci A, Bruno O, Covani U, Barone A,etal. Surface roughness of commercial composites after different polishing protocols: an analysis with atomic force microscopy. Open Dent J 2010;4:191-4. [CrossRef]

10. Lu H, Roeder LB, Lei L, Powers JM. Effect of surface roughness on stain resistance of dental resin composites. J Esthet and Restor Dent 2005;17:102-8. [CrossRef]

11. Korkmaz Y, Ozel E, Attar N, Aksoy G. The influence of one-step polishing systems on the surface roughness and microhardness of nanocomposites. Oper Dent 2008;33:44-50. [CrossRef]

12. Bollen $C M$, Lambrechts $P$, Quirynen $M$. Comparison of surface roughness of oral hard materials to the threshold surface roughness for bacterial plaque retention. A review of the literature. Dent Mat 1997;13:258-69. [CrossRef]

13. Reis AF, Giannini M, Lovadino JR, dos Santos Dias CT. The effect of six polishing systems on the surface roughness of two packable resin-based composites. Am J Dent 2002;15:193-7.

14. Chung K. Effects of finishing and polishing procedures on the surface texture of resin composites. Dent Mater 1994;5:325-30. [CrossRef]

15. Ergucu Z,Turkun LS. Surface roughness of novel resin composites polished with one-step systems. Oper Dent 2007;32-2:185-92. [CrossRef]

16. Moszner N, Salz U. New developments of polymeric dental composites. Prog Polym Sci 2001;26:535-76. [CrossRef]

17. Ozgunaltay G, YazıCI AR, Gorucu J. Effect of finishing and polishing procedures on the surface roughness of new toothcoloured restoratives. J Oral Rehabil 2003;30:218-24. [CrossRef] 
18. Paravina RD, Roeder L, Lu H, Vogel K, Powers JM. Effect of finishing and polishing procedures on surface roughness, gloss and color of resin-based composites. Am J Dent 2004;17:262-6.

19. Bayne SC, Heymann HO, Swift EJ Jr. Update on dental composite restorations. J Am Dent Assoc 1994;125:687-701. [CrossRef]

20. Lee YK, Powers JM. Combined effects of staining substances on resin composites before and after surface sealant application. J Mater Sci Mater Med 2007;18:685-91. [CrossRef]

21. dos Santos PH, Consani S, Sobrinho LC, Sinhoreti MA. Effect of surface penetrating sealant on roughness of posterior composite resins. Am J of Dent 2003;16:197-201.

22. dos Santos PH, Pavan S, Consani S, Sobrinho LC, Sinhoreti MA, Filho JN. In vitro evaluation of surface roughness of 4 resin composites after the toothbrushing process and methods to recover superficial smoothness. Quintessence Int 2007;38:247-53.

23. Güler AU, Yilmaz F, Kulunk T, Guler E, Kurt S. Effects of different drinks on stainability of resin composite provisional restorative materials. J Prosthet Dent 2005;2:118-24. [CrossRef]

24. Sen $D$, Goller $G$, Issever $H$. The effect of two polishing pastes on the surface roughness of bis-acryl composite and methacrylatebased resins. J Prosthet Dent 2002;5:527-32. [CrossRef]

25. Dickinson GL, Leinfelder KF, Mazer RB, Russell CM. Effect of surface penetrating sealant on wear rate of posterior composite resins. J Am Dent Assoc 1990;121:251-55. [CrossRef]

26. Prakki A, Ribeiro IWJ, Cilli R, Mondelli RFL. Assessing the toothrestoration interface wear resistance of two cementation techniques: effect of a surface sealant. Oper Dent 2005;30:739-46.

27. Ramos RP, Chimello DT, Chinelatti MA, Dibb RG, Mondelli J. Effect of three surface sealants on marginal sealing of class $V$ composite resin restorations. Oper Dent 2000;25:448- 53.

28. Barghi N, Alexander C. A new surface sealant for polishing composite resin restorations. Compend Contin Educ Dent 2003;24:30-3.

29. Roeder LB, Tate WH, Powers JM. Effect of finishing and polishing procedures on the surface roughness of packable composites. Oper Dent 2000;25:534-43.

30. Sarac D, Sarac YS, Kulunk S, Ural C, Kulunk T. The effect of polishing techniques on the surface roughness and color change of composite resins. J Prosthet Dent 2006;96:33-40. [CrossRef]

31. Takeuchi CYG, Orbegoso Flores VH, Palma Dibb RG, Panzeri $H$, Lara EHG, Dinelli W. Assessing the surface roughness of a posterior resin composite: effect of surface sealing. Oper Dent 2003;28:283-8.

32. Dickinson GL, Leinfelder KF. Assessing the long-term effect of a surface penetrating sealant. J Am Dent Assoc 1993;124:68-72. [CrossRef]

33. Moraes LGP, Rocha RsF, Menrgazzo LM, Araujo EB, Yukimitu K, Moraes JCS. Infrared spectroscopy: a tool for determination of the degree of conversion in dental composites. J Appl Oral Sci 2008;16:145-9. [CrossRef]

34. Yıkılgan I, Kamak H, Akgul S, Ozcan S, Bala O. Effects of three different bleaching agents on microhardness and roughness of composite sample surfaces finished with different polishing techniques. J Clin Exp Dent 2017;9:e460-5. [CrossRef]

35. Shafiei F, Doustfatemeh S. Effect of a Combined Bleaching Regimen on the Microhardness of a Sealed Methacrylate-based and a Silorane-based Composite. J Dent Shiraz Univ Med Sci, 2013;14:111-7.

36. Tekce N, Pala K, Tuncer S, Demirci M. The effect of surface sealant application and accelerated aging on posterior restorative surfaces: An SEM and AFM study. Dent Mater J 2017;36:182-9. [CrossRef]

37. Alrahlah A, Silikas N, Watts DC. Post-cure depth of cure of bulk fill dental resin- composites. Dent Mater 2014;30:149-54. [CrossRef]

38. El-Damanhoury H, Platt J. Polymerization shrinkage stress kinetics and related properties of bulk-fill resin composites. Oper Dent 2014;39:374-82. [CrossRef]
39. Czasch P, Ilie N. In vitro comparison of mechanical properties and degree of cure of bulk fill composites. Clin Oral Investig 2013;17:227-35. [CrossRef]

40. Leprince JG, Palin WM, Vanacker J, Sabbagh J, Devaux J, Leloup G. Physico-mechanical characteristics of commercially available bulk-fill composites. J Dent 2014;42:993-1000. [CrossRef]

41. DoT, Church B, Veríssimo C, Hackmyer SP, Tantbirojn D, Simon JF, Versluis A. Cuspal flexure, depth-of-cure, and bond integrity of bulk-fill composites. Pediatr Dent 2014;36:468-73.

42. Fronza BM, Rueggeberg FA, Braga RR, Mogilevych B, Soares LE, Martin AA, Ambrosano G, Giannini M. Monomer conversion, microhardness, internal marginal adaptation, and shrinkage stress of bulk-fill resin composites. Dent Mater 2015;31:1542-51. [CrossRef]

43. Garoushi S, Vallittu P, Shinya A, Lassila L. Influence of increment thickness on light transmission, degree of conversion and micro hardness of bulk fill composites. Odontology 2016;104:291-7. [CrossRef]

44. Galvao MR, Caldas SG, Bagnato VS, Rastelli AN, Andrade MF. Evaluation of degree of conversion and hardness of dental composites photoactivated with different light guide tips. Eur J Dent 2013;7:86-93.

45. Whitehead, SA, Shearer, AC, Watts, DC, Wilson, NH, 1995. Comparison of methods for measuring surface roughness of ceramic. J Oral Rehabil 1995;22:421-7. [CrossRef]

46. Lopes MB, Saquy PC, Moura SK, Wang L, Graciano FMO, Correr Sobrınho L, Gonını júnıor A. Effect of Different Surface Penetrating Sealants on the Roughness of a Nanofiller Composite Resin. Braz Dent J 2012;23:692-7. [CrossRef]

47. D'Alpino PH, Pereira JC, Rueggeberg FA, Svizero NR, Miyake $\mathrm{K}$, Pashley DH. Efficacy of composite surface sealers in sealing cavosurface marginal gaps. J Dent 2006;34:252-9. [CrossRef]

48. Yap AUJ, WU SS, Chelvan S, Tan ESF. Effect of hygiene maintenance procedures on surface roughness of composite restoratives. Oper Dent 2005;30:99-104.

49. Kawai K, Leinfelder KF. Effect of surface-penetrating sealant on composite wear. Dent Mater 1993;9:108-13. [CrossRef]

50. Van Dijken JW, Sjöström S, Wing K. The effect of different types of composite resin fillings on marginal gingiva. J Clin Periodontol 1987;14:185-9. [CrossRef]

51. Doray PA, Eldiwany MS, Powers JM. Effect of resin surface sealers on improvement of stain resistance for a composite provisional material. J Esthet Restor Dent 2003;15:244-50. [CrossRef]

52. Shintani H, Satou J, Satou N, Hayashihara H, Inoue T. Effect of various finishing methods on staining and accumulation of Streptococcus mutans HS-6 on composite resin. Dent Mater 1985; 1:225-7. [CrossRef]

53. Willems $G$, Lambrechts $P$, Braem $M$, Vuylsteke-Wauters $M$, Vanherle $G$. The surface roughness of enamel-to-enamel contact areas compared with the intrinsic roughness of dental resin composites. J Dent Res 1991;70:1299-305. [CrossRef]

54. Heintze SD, Forjanic M, Rousson V. Surface roughness and gloss of dental materials as a function of force and polishing time in vitro. Dent Mater 2006;22:146-65. [CrossRef]

55. Leprince JG, Palin WM, Mullier T, Devaux J, Vreven J, Leloup G. Investigating filler morphology and mechanical properties of new low-shrinkage resin composite types. J Oral Rehabil 2010;37:364-76. [CrossRef]

56. Knobloch LA, Kerby RE, Clelland N, Lee j. Hardness and degree of conversion of posterior packable composites. Oper Dent 2004;9:642-9.

57. Bucutas S, Ilie N. Light transmittance and micro-mechanical properties of bulk-fill vs conventional resin composites. Clin Oral Invest 2014;18:1991-2000. [CrossRef]

58. Hahnel S, Dowling AH, El-Safty S, Fleming GJP. The influence of monomeric resin and filler characteristics on the performance of experimental resin-based composites (RBCs) derived from a commercial formulation. Dent Mater 2012;28:416-23. [CrossRef] 
59. Mobarak E, Elsayed I, Ibrahim M, El-Badrawy W. Effect of LED light-curing on the relative hardness of tooth-colored restorative materials. Oper Dent 2009;34:65-71. [CrossRef]

60. Boyer DB, Chalkley $Y$ \& Chan KC. Correlation between strength of bonding to enamel and mechanical properties of dental composites. Journal of Biomedical Materials Research 1982;16:775-83. [CrossRef]

61. Chung $\mathrm{KH}$. The relationship between composition and properties of posterior resin composites. Journal of Dental Research 1990;69:852-6. [CrossRef]
62. Abed YA, Sabry HA. Alrobeigy. Degree of conversion and surface hardness of bulk-fill composite versus incremental-fill composite. Tanta Dental Journal 2015;12:71-80. [CrossRef]

63. Thome T, Steagall JrW, Tachibana, et al. Influence of distance of curing light source and composite shade on hardness of two composites. J Appl Oral Sci 2007;15:486-941. [CrossRef]

64. Kim EH, Jung KH, Son SA, Hur B, Kwon YH, Park JK. Effect of resin thickness on the microhardness and optical properties of bulk-fill resin composites. Restor Dent Endod 2015;40:128-35. [CrossRef] 